\title{
Price Interactions between Wild and Farmed Products: Turkish Sea
}

\author{
Bass and Sea Bream Markets
}

12.07.2018

\section{Basak BAYRAMOGLU ${ }^{1}$}

\begin{abstract}
We investigate empirically market interactions in the Turkish wild and farmed sea bass and sea bream markets. For gilthead sea bream and European sea bass, we conduct a Granger causality test between the prices of the wild and farmed products, based on the estimation of a vector autoregressive model. Our data set consists of annual fish prices from 1996 to 2016. Our empirical results show that the wild and farmed sea bass are neither substitutes nor complements : the markets for each product are independent. However, in the case of sea bream, the price variations for farmed sea bream have a causal impact on the price of wild sea bream. Moreover, the price of wild sea bream Granger-causes the price variation of farmed sea bream. Thus, the wild and farmed sea bream markets are integrated.
\end{abstract}

Keywords: farmed fish, wild fish, market interactions, Turkey, sea bass, sea bream.

JEL Codes: C32; Q22.

\footnotetext{
${ }^{1}$ Economie Publique, INRA, AgroParisTech, Université Paris-Saclay, 78850 Thiverval-Grignon, France. E-mail: Basak.Bayramoglu@inra.fr. I am grateful for very helpful comments from the referees. I am also grateful for detailed and helpful comments by Jean-François Jacques. Some of the data in this paper were gathered by Iaad Ben Dhia during his internship at INRA, UMR Economie Publique.
} 


\section{Introduction}

Turkey is one the main producers and exporters of farmed sea bass and sea bream in Europe. In the case of European sea bass (Dicentrarchus labrax), Turkey is the largest producer in Europe, followed by Greece; the ranking is reversed for gilthead sea bream (Sparus auratus) (FEAP, 2014). Export of these products is booming in Turkey; imports of sea bass and sea bream by the main European Union (EU) markets increased by $200 \%$ between 2010 and 2015 compared to a $20 \%$ reduction in imports from Greece (EUFOMA, 2016). Turkey also catches wild sea bass and sea bream making the Turkish market an interesting case to investigate market interactions in the wild and farmed sea bass and sea bream markets. The Turkish market is important also because the market conditions for these species in Turkey have direct impacts on the European fish market, and vice versa.

Turkey has large and diverse aquatic resources thanks to its geography which includes 8,333 $\mathrm{km}$ of coastline, a total $177,714 \mathrm{~km}$ of river length, and 900,000 ha of natural lakes. Despite its rich water resources, Turkish marine fisheries production has stagnated. There are several factors at the origin of this phenomenon: over-exploitation of fishery resources and marine pollution (Ulman et al., 2013). In response to lower yields from its marine fisheries, production activities were launched in the 1970s to farm common carp and rainbow trout (Oncorhynchus mykiss) (Rad and Rad, 2012). Production of sea bass and sea bream started later in the mid-1980s which makes the farming of sea bass and sea bream a rather young industry (Okumus and Deniz, 2007).

Since the 1990s, aquaculture production has increased rapidly, and especially production of sea bream, sea bass, and rainbow trout. In 2016, aquaculture production represented 
approximately $48.8 \%$ of total seafood production in Turkey (Turkish Statistics Institute, ${ }^{2}$ TurkStat, 2017). Marine aquaculture is the main supplier of cultivated products followed by inland aquaculture, with respective shares in total aquaculture production of $59.9 \%$ and $40.1 \%$. The situation is different for rainbow trout where $96 \%$ of the aquaculture production came from inland water resources in 2013 (TurkStat). The main characteristics of the marine aquaculture sector in Turkey are limited species diversity (mainly rainbow trout, sea bass, and sea bream), limited system diversity (cages), the number of small farms, and the dependence on EU export markets (Okumus and Deniz, 2007). Another characteristic of the Turkish aquaculture sector is its geographical concentration; $92 \%$ of cage farms for aquaculture production are located in the Aegean region based on its convenient geographical and hydrographical conditions (Harlioglu, 2011). Rainbow trout is ranked first (114 569 tons in 2013, including inland and marine production) for cultivated fish species production followed by sea bass (51 600 tons in 2013) and sea bream (41 700 tons in 2013) (FEAP, 2014).

Consumption of seafood in Turkey is low, with annual per capita consumption of $6.1 \mathrm{~kg}$ in 2013, well below the European average of $21.9 \mathrm{~kg}$, and the world average of $19.2 \mathrm{~kg}$ (Faostat data on food balance sheets, food supply quantity in $\mathrm{kg}$ /capita/year). ${ }^{3}$ Turkish consumers prefer to eat meat and poultry rather than fish. The ratio of consumption of meat to fish was to 5.07 in 2003 (Househould Budget Survey micro data, 2003, TurkStat). The low level of consumption of fish could be explained by dietary habits and the volatility of marine fish prices because of seasonal variations in supply. However, there is large heterogeneity in consumption among coastal and inland regions. For instance, yearly consumption per capita is 20-25 $\mathrm{kg}$ in the eastern Black sea region compared to only $1 \mathrm{~kg}$ in east and south-east Anatolia (Ergun, 2009).

\footnotetext{
${ }^{2}$ http://www.turkstat.gov.tr/Start.do.

${ }^{3}$ http://www.fao.org/faostat/en/\#data.
} 
Our goal in this study is to examine price interactions between farmed and wild products in the Turkish sea bass and sea bream markets. This should provide insights into the extent to which the farmed fish price is likely to affect the wild fish price, and in turn, might indicate the related effects on marine fishing activities and wild fish stocks. For a given fish species, if farmed and wild fish are substitutes, then we should observe a positive relationship between the prices of the two goods. More precisely, in that case, a shift in the price of one good should result in a positive percentage variation in the price of the other good. For example, lower farmed fish prices thanks to higher levels of farmed production could lead to a decrease in wild fish prices if the two products are substitutes in the market. In contrast, if farmed and wild fish are complements, then we should observe a negative relationship between the prices of the two goods, more precisely, an increase in the price of one good should result in a decrease in the price of the other good.

In the empirical literature, market integration tests usually involve cointegration analysis on non-stationary price series. The findings from previous empirical investigations indicate that ñfarmed species competes mainly with the same wild species (and other species in the same segment), but not with other speciesò (Asche et al., 2001, p. 311). In the case of salmon which is the most frequent studied species in empirical applications, there is evidence of a highly integrated market for wild and farmed products (Asche et al., 2001; Asche et al., 2005; Knapp et al., 2007). Also, in the case of white fish, the existing studies report a relatively integrated market (Asche et al., 2002; Nielsen, 2005).

In the context of sea bass and sea bream, the results of the scarce empirical studies are mixed. Brigante and Lem (2001) find no evidence of a price link between farmed and wild sea bass and sea bream in the Italian market. Similarly, Rodriguez et al. (2013) find that the price series of farmed and wild gilthead sea bream in the Spanish market are not cointegrated. Again for the Spanish market, Bjorndal and Guillen (2017) show that there is no market 
integration between wild and farmed species of gilthead seabream and European seabass. However, Regnier and Bayramoglu (2015) who study the case of France, find evidence of a partial market integration between wild and farmed sea bream although not for sea bass. They find that the price series of wild and farmed sea bream are cointegrated but that the Law of One Price does not hold, meaning that these products are imperfect substitutes.

Existing work on the Turkish sea bass and sea bream markets focuses mainly on evaluation of the operational costs of production of these species (Kocak and Tatlidil, 2004; Bozoglu and Ceyhan, 2009), on the economic analysis of the main Turkish marine hatcheries specialized in sea bass and sea bream production (Kurtoglu et al., 2010), and on the comparison of the Turkish and EU aquaculture sectors (Aydin et al., 2014).

In the present paper, we provide descriptive statistics of the price dynamics in Turkish wild and farmed sea bass and sea bream markets. We also conduct a Granger causality test between the prices of wild and farmed sea bass and sea bream, based on estimation of a vector autoregressive model. Granger causality tests allow us to take account of the dynamic interactions between markets. This analysis exploits TurkStat data on annual domestic fish prices from 1996 to 2016. Although our sample size is small, this data set provides information on price data disaggregated between farmed and wild species, data which are rarely available (Bjorndal and Guillen, 2017).

Section 2 describes the patterns of production of sea bass and sea bream in Turkey. Section 3 describes the Turkish sea bass and sea bream markets, the data set and the descriptive statistics. Section 4 presents the econometric methodology and the estimation results. Section 5 concludes by summarizing our main results. 


\section{Production of sea bass and sea bream in}

\section{Turkey}

Rad (2002), Harlioglu (2011) and Ulman et al. (2013) provide detailed descriptions of the Turkish fishery sector while Rad and Koksal (2000) and Okumus and Deniz (2007) are sources of information on the Turkish aquaculture sector. FEAP (2014) presents some interesting statistics on European aquaculture including Turkey. Our study focuses on the development of the Turkish aquaculture sector over the recent period 1996 to 2016.

In Turkey, public policies, including subsidies especially for farmed sea bass, sea bream and trout production, have had a positive influence on the rapid growth of the aquaculture sector. . In 2012, farms with annual production capacity up to 251 tons benefited from the following unit subsidies: $0.85 \mathrm{TL}^{4} / \mathrm{kg}$ for sea bass and sea bream, $0.65 \mathrm{TL} / \mathrm{kg}$ for trout, $0.20 \mathrm{TL} / \mathrm{kg}$ for mussels, $0.06 \mathrm{TL} / \mathrm{unit}$ for juveniles, and $1 \mathrm{TL} / \mathrm{kg}$ for new species. To preserve competitiveness in the Turkish aquaculture sector, farms with production capacity of between 215 tons/ year and 500 tons/year received subsidies amounting to only half of that received by smaller farms although for organic aquaculture production, the amount of these unit subsidies is doubled. In 2011, the shares of the overall subsidies available to the aquaculture sector were: $55.91 \%$ to trout, $23.78 \%$ to sea bass, $19.47 \%$ to sea bream, and $0.83 \%$ to other species (SPO, 2014).

Kocak and Tatlidil (2004) conducted a production cost analysis of gilthead sea bream and sea bass farms in the Aegean Sea in the Milas District of Mugla Province. They gathered information from 24 farms engaged in the production of these species. They found that total

\footnotetext{
${ }^{4} \mathrm{TL}$ is Turkish Lira. The exchange rate with the USD and the EUR in 2016 (resp. in 2018) are respectively: 3.03 (resp. 3.80) and 3.35 (resp. 4.67) (www.tcmb.gov.tr).
} 
production costs consisted of 95\% variable costs and 5\% fixed costs and that the per-unit costs of gilthead sea bream $(\$ 2.48 / \mathrm{kg})$ were higher than for sea bass $(\$ 2.34 / \mathrm{kg})$. Bozoglu and Ceyhan (2009) studies the cost structure of the main mariculture farms located in the Black Sea (9 in total) in 2005-2006. They find that the per-unit cost of sea bass in the Black Sea is higher than in the Aegean Sea $(\$ 4.77 / \mathrm{kg})$. The costs of sea bass production include feed (47.73\%), labor (23\%), juveniles (10\%), and marketing costs (7\%).

We exploit TurkStat data which provides annual marine fishery catches and aquaculture production statistics for 1996 to 2016. Average quantities are: 990 tons for wild sea bream, 25 743 tons for farmed sea bream, 1111 tons for wild sea bass, and 38215 tons for farmed sea bass. Note that, for both sea bass and sea bream, aquaculture production is the main source of supply. The data show that the average share of aquaculture in total supply is $96 \%$ for sea bream, and $97 \%$ for sea bass. Note also, that there is non-negligible temporal variation in quantities of both farmed and wild species. Comparison of figures 1 and 2 reveals first that the wild market is more volatile due to seasonal variations in supply compared to farmed production which shows a steady increase in production over the whole period. Figure 1 shows that, from 2002, catches of sea bream exceed those of sea bass. 


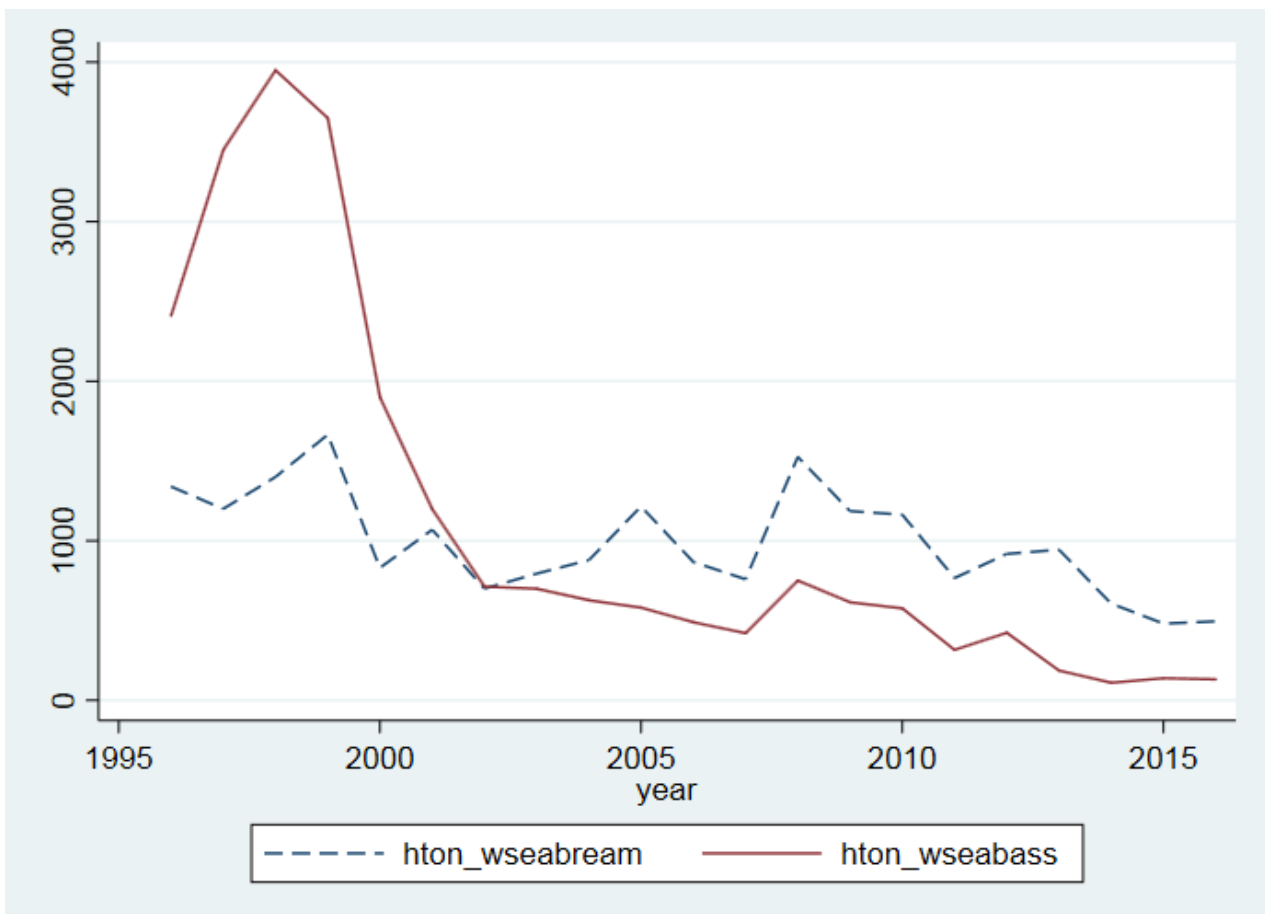

Figure 1: Information on marine catches: sea bream and sea bass (tons)

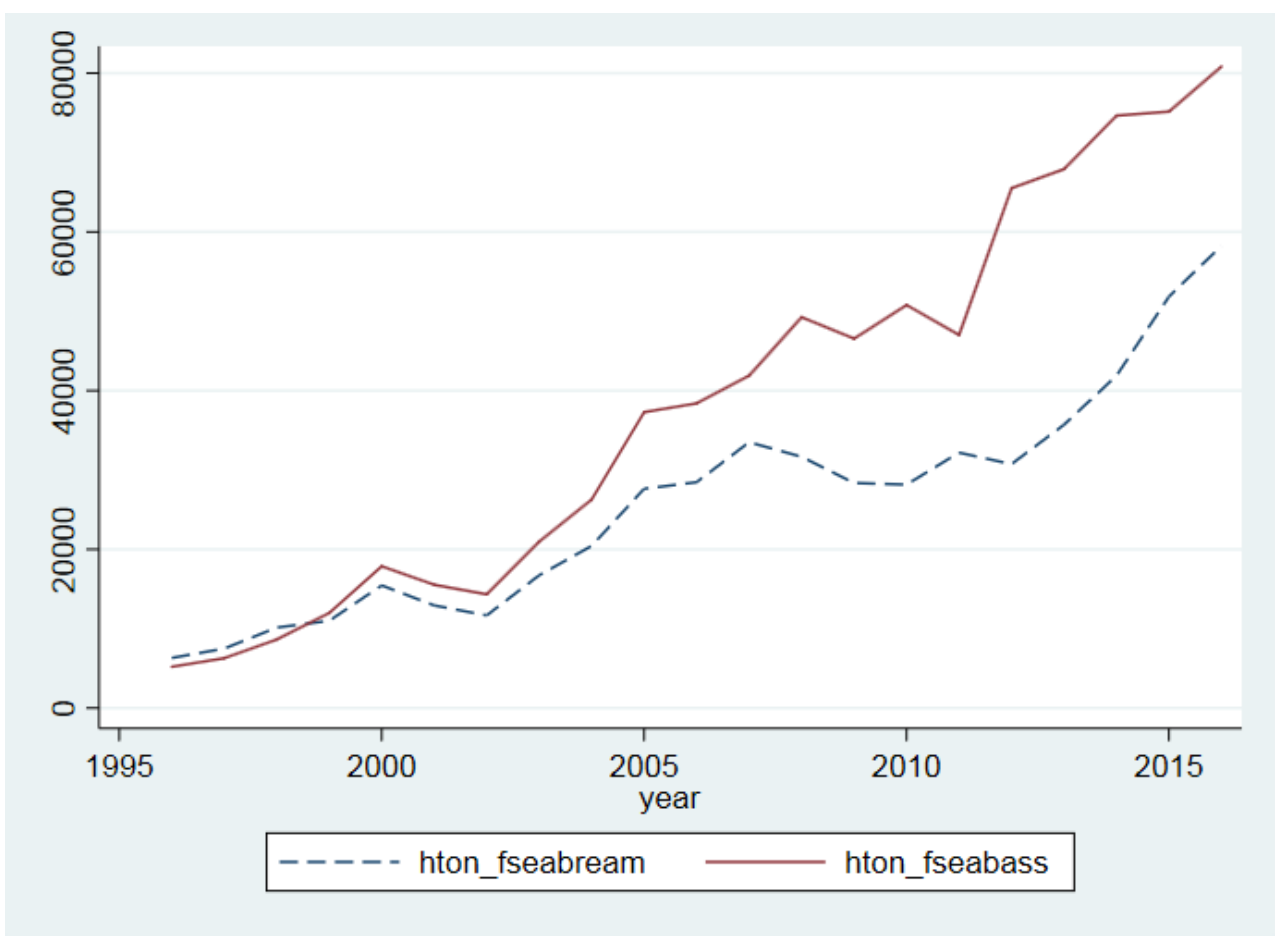

Figure 2: Information on farmed production: sea bream and sea bass (tons) 
Figure 2 shows that the farmed production increased steadily between 1996 and 2016 with a peak in 2014, and that farmed sea bass production outperformed that of sea bream across most of the period.

\section{Sea bass and sea bream markets in}

\section{Turkey}

Traditionally in Turkey, the most consumed species is anchovy. Other dominant species in the Turkish market are sardine and horse mackerel which are low-priced due to large national marine production. This contrasts with turbot, sea bass, and sea bream which are high-value species and are consumed by high income consumers and the tourism sector (Ergun, 2009). Table 13 in the appendix shows the ranking of fresh fish species based on consumption in 2003. The data show that among 39 species, consumption by Turkish consumers of trout, sea bream, and sea bass is ranked respectively $9^{\text {th }}, 10^{\text {th }}$ and $14^{\text {th }}$.

Farmed sea bass and sea bream are cheaper than the wild product. TurkStat indicates that in 2016, the price of farmed sea bream was $10.48 \mathrm{TL} / \mathrm{kg}$ and $20.28 \mathrm{TL} / \mathrm{kg}$ for the wild product. In the case of sea bass, the farmed product costs $16.8 \mathrm{TL} / \mathrm{kg}$ and the wild product $27.57 \mathrm{TL} / \mathrm{kg}$ (TurkStat, fisheries statistics). This can be explained in part by the larger production volumes of the farmed compared to the wild product for both species. Moreover, ñFarmed sea bass and sea bream are available in every super market or retail fish shops throughout the year, with more or less stable prices for standard size categories. This is not the case for capture fisheries products, whether of marine or freshwater originsò ( $\operatorname{Rad}$ and $\operatorname{Rad}, 2012$, p. 358). 
We do not have information on the domestic consumption of wild and farmed products separately for a given species. SPO $(2014$, p. 80$)$ provides trade statistics for sea bass and sea bream in the period 2008-2011 (table 1).

Table 1: Trade statistics for sea bass and sea bream

\begin{tabular}{|l|l|l|l|}
\hline $\begin{array}{l}\text { Yearly average 2008-2011 } \\
\text { (in tons) }\end{array}$ & Exports & Imports & Net exports \\
\hline Sea bream & 8005 & 9.609 & 7995 \\
\hline Sea bass & 12633 & 54.046 & 12579 \\
\hline
\end{tabular}

Table 1 shows that net exports are positive for sea bream and sea bass. Net exports of sea bass are the larger thanks to larger marine catches and larger aquaculture production for this species.

Akova (2015) reports that sea bass is exported mostly to the Netherlands, Libya, the UK, Italy and Germany, and sea bream to Lebanon, the Netherlands, Libya, Italy, Germany, and the UK. EUNETMAR (2014, p. 15) underlines that Turkey ñhas a 25\% market share in seabass and seabream trade in Europe. ò Between 2010 and 2016, Turkish exports of sea bass and sea bream to Europe increased by $134 \%$ and $498 \%$ respectively. In this period, Turkey gained remarkable market share over Greece for supply of sea bass and sea bream to Italy and markets in northern Europeï Netherlands, Germany, UK, and Belgium (EUFOMA, 2017).

Regarding shares of exported fish production, the literature and the existing data offer different pictures at different points in time. In the case of cultivated sea bass and sea bream, Rad and Koksal (2000) note that in 1996, $80 \%$ of production was exported mainly to Italy, 
Greece, and France. Between 2005-2007, Ozguler (2007) reports that $44 \%$ of cultivated sea bass production and $18 \%$ of cultivated sea bream production were exported.

We conducted our own estimates of the share of exported fish production for sea bass and sea bream for 2008-2011, based on export data from SPO (2014) combined with TurkStat data on (wild and farmed) fish production quantities (table 2).

Table 2: Share of exports in total production for sea bass and sea bream

\begin{tabular}{|c|c|c|c|}
\hline $\begin{array}{l}\text { Yearly average } \\
2008-2011 \text { (in } \\
\text { tons) }\end{array}$ & Exports & $\begin{array}{l}\text { Total (wild and } \\
\text { farmed) production }\end{array}$ & $\begin{array}{l}\text { Share of exports } \\
\text { in total } \\
\text { production }\end{array}$ \\
\hline Sea bream & 8005 & 31254 & $26 \%$ \\
\hline Sea bass & 12633 & 48973 & $26 \%$ \\
\hline
\end{tabular}

We calculate that the share of exports in total production is $26 \%$ for both sea bass and sea bream. All these sources of information indicate that the share of exported fish production for these species has decreased over time. This is explained by the larger increases in production volumes compared to increases in exported quantities over time.

\section{III.1- The data set}

The data are drawn from TurkStat which provides annual statistics on the marine fishery and aquaculture sector between 1996 and 2016. These statistics come from surveys of professional fishermen and aquaculture farms. Catches of marine fish and farmed production quantities, 
expressed initially in tons were transformed to $\mathrm{kg}$. Fish prices are expressed in TL per kg. To obtain a constant fish price (TL 2003), these data are deflated by the Consumer Price Index (CPI, base year 2003) constructed from inflation statistics for Turkey provided by IMF (2017). Below, we describe the price data.

\section{III.2- Descriptive statistics}

Table 3 presents descriptive statistics of the deflated fish prices (TL/kg).

Table 3: Descriptive statistics of the variables

\begin{tabular}{|l|l|l|l|l|l|}
\hline Variable & Obs. & Mean & Std.Dev. & Min & Max \\
\hline Price wild sea bream & 21 & 9.24 & 2.56 & 5.20 & 15.90 \\
\hline Price farmed sea bream & 21 & 6.76 & 3.31 & 3.56 & 14.76 \\
\hline Price wild sea bass & 21 & 10.93 & 3.16 & 4.98 & 18.55 \\
\hline Price farmed sea bass & 21 & 7.40 & 3.96 & 4.48 & 17.22 \\
\hline
\end{tabular}

For both fish species, the deflated prices of the farmed products are lower than the prices of the wild products, and wild see bass is more expensive than wild sea bream. There is a nonnegligible temporal variation in the prices of both the farmed and the wild species. We analyze these data in more detail below.

For sea bream, figure 3 shows that the prices of the farmed and wild products follow similar declining trends over time although after 2004 the farmed price drops more dramatically than 
the wild price. Note also that with the exception of the beginning of the period, the farmed product is always cheaper than the wild one.

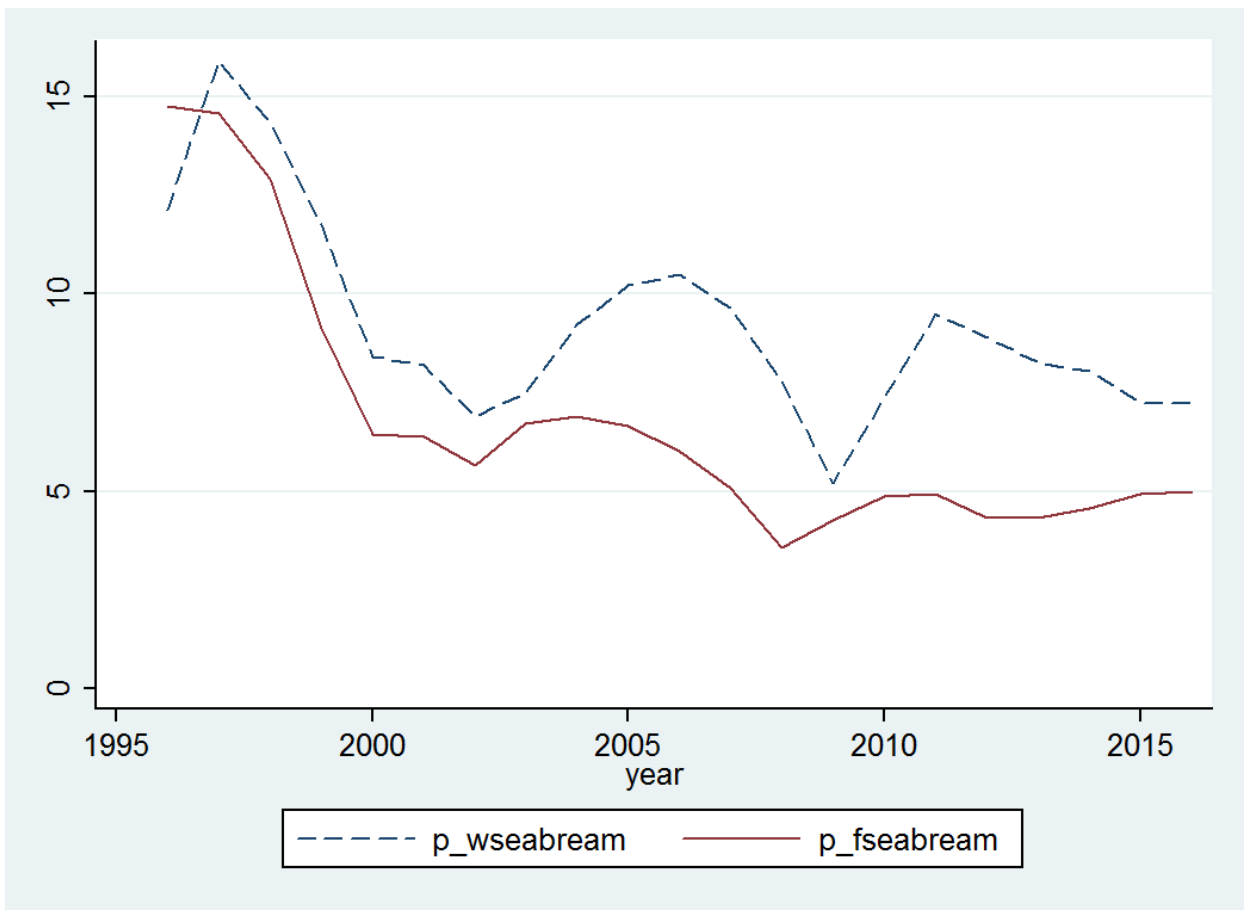

Figure 3: Price dynamics: wild versus farmed sea bream (prices in constant TL per kg, base year 2003)

In contrast, figure 4 shows that for sea bass, the trends in the prices of farmed and wild products differ over time. The period is delimited by two price breaks in 2004 and 2009 after which the price of wild sea bass greatly exceeds the price of farmed sea bass. 


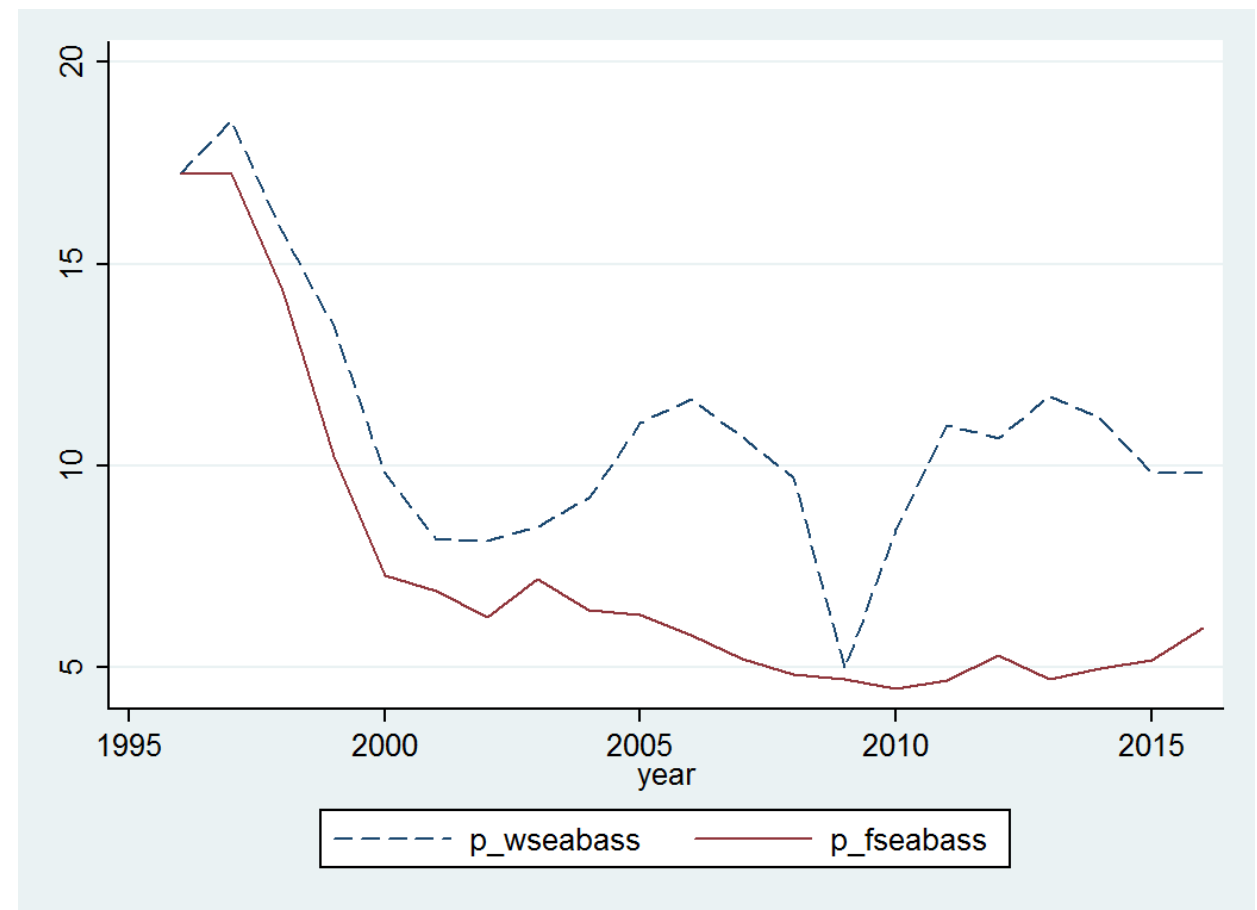

Figure 4: Price dynamics: wild versus farmed sea bass (prices in constant TL per kg, base year 2003)

To further investigate the relationship between the prices of wild and farmed products for each species, we look next at the pairwise correlations (table 4).

Table 4: Pairwise correlations between the prices of wild and farmed products

\begin{tabular}{|l|l|l|l|l|}
\hline & Wild sea bream & Farmed sea bream & Wild sea bass & Farmed sea bass \\
\hline Wild sea bream & 1 & & & \\
\hline Farmed sea & $0.8564^{*}$ & 1 & & \\
\hline Wild sea bass & $0.9256^{*}$ & $0.8369^{*}$ & 1 & \\
\hline Farmed sea bass & $0.8343^{*}$ & $0.9889^{*}$ & $0.8438^{*}$ & 1 \\
\hline
\end{tabular}

* denotes $1 \%$ significant level.

Table 4 shows that in the case of sea bream, there is a strong positive correlation between the prices of the wild and farmed products (86\%). This correlation is slightly lower for sea bass 
$(84 \%)$. What is more particular is the strong positive correlation between the prices of the farmed products, and the wild products of the different species: farmed sea bass and farmed sea bream (99\%), and wild sea bass and wild sea bream (92\%).

\section{Empirical methodology and results}

\section{IV.1- Empirical methodology}

Here, we consider a vector autoregressive (VAR) model with two variables $y$ and $x$ and two lags:

$$
\begin{aligned}
& y_{t}=a_{y}+b_{y 1} y_{t-1}+b_{y 2} y_{t-2}+c_{y 1} x_{t-1}+c_{y 2} x_{t-2}+v_{y t} \\
& x_{t}=a_{x}+b_{x 1} y_{t-1}+b_{x 2} y_{t-2}+c_{x 1} x_{t-1}+c_{x 2} x_{t-2}+v_{x t}
\end{aligned}
$$

In this model, each variable is a function of both its own lagged values and the lagged values of the other variable. The two variables are assumed to be stationary (Bourbonnais, 2000).

$v_{y t}$ is an error term with zero mean and constant variance $\sigma_{v y}^{2}$ and

$v_{x t}$ is an error term with zero mean and constant variance $\sigma_{v x}^{2}$.

Granger (1969) proposed the concepts of causality and exogeneity: the variable $x$ is the cause of $y$ if the predictability of $y$ is improved when information about $x$ is incorporated in the analysis (Hamilton, 1994).

Consider the VAR model with two stationary variables $y$ and $x$, and two lags written in matrix form: 


$$
\left[\begin{array}{l}
y_{t} \\
x_{t}
\end{array}\right]=\left[\begin{array}{l}
a_{y} \\
a_{x}
\end{array}\right]+\left[\begin{array}{ll}
b_{y 1} & c_{y 1} \\
b_{x 1} & c_{x 1}
\end{array}\right]\left[\begin{array}{l}
y_{t-1} \\
x_{t-1}
\end{array}\right]+\left[\begin{array}{ll}
b_{y 2} & c_{y 2} \\
b_{x 2} & c_{x 2}
\end{array}\right]\left[\begin{array}{l}
y_{t-2} \\
x_{t-2}
\end{array}\right]+\left[\begin{array}{l}
v_{y t} \\
v_{x t}
\end{array}\right]
$$

- $\quad x_{t}$ does not Granger-cause $y_{t}$ if the following null hypothesis $\mathrm{H} 0$ is accepted:

$$
c_{y 1}=c_{y 2}=0 .
$$

- $y_{t}$ does not Granger-cause $x_{t}$ if the following null hypothesis $\mathrm{H} 0$ is accepted:

$$
\mathrm{b}_{x 1}=\mathrm{b}_{x 2}=0
$$

Non-stationary series may lead to spurious regression (Granger and Newbold, 1974). The spurious regression has a high coefficient of determination $\mathrm{R}^{2}$ and leads to significant coefficients. These results are, however, meaningless from an economic point of view because all errors are permanent. More specifically, if the sequences $\left\{y_{t}\right\}$ and $\left\{x_{t}\right\}$ in Equation 1 are non-stationary and integrated of the same order, and the residual sequence includes a stochastic trend, then the regression is spurious (Enders, 2004). In order to avoid this problem, we start by studying the stationarity of the underlying price series.

\section{IV.2- Empirical results}

Tables 5 and 6 report respectively the results of the augmented Dickey-Fuller (ADF) unit root test for the price series of sea bass and sea bream. 
Given the small sample size, we select a maximum of two lags for all price series. ${ }^{5}$ We test the most appropriate specification among the models underlying the ADF test. ${ }^{6}$ For all price series except farmed sea bream, the test statistics are lower than the critical values reported in the second columns of tables 5 and 6 , implying the absence of a unit root, i.e. the null hypothesis of non-stationarity is rejected at the 5\% significance level. Since we cannot reject the non-stationarity of the price series of farmed sea bream, ${ }^{7}$ we take the first-differences. Table 6 columns 3 and 5 show that for farmed sea bream prices in first-differences, the null hypothesis of non-stationarity is rejected at the $10 \%$ significance level. Two other unit-root tests, namely Phillips and Perron (1988) and Elliott, Rothenberg and Stock (1996) confirm at the $5 \%$ significance level, that farmed sea bream prices in first-difference are stationary. ${ }^{8}$

Evidence of stationarity allows us to conduct Granger causality tests between the price series of interest based on the estimation of a VAR model.

Table 5: ADF tests for unit roots in price series of sea bass

\begin{tabular}{|l|l|l|}
\hline Prices in log & Test statistic level & Critical value (5\%) \\
\hline Wild sea bass & $-3.132^{* *}$ & -3.000 \\
\hline Farmed sea bass & $-3.938^{* *}$ & -3.000 \\
\hline
\end{tabular}

** Statistically significant at the $5 \%$ level.

\footnotetext{
${ }^{5}$ For space reasons, we provide the ADF test results with one lag. The results with two lags are available on request from the authors.

${ }^{6}$ For each variable, we tested the relevance of adding a constant term and a trend intercept for the explanatory power of the specification.

${ }^{7}$ We also conducted the Phillips-Perron (1988) and Elliott-Rothenberg-Stock (1996) unit-root tests for farmed sea bream prices with one and two lags. In each case, the null hypothesis of non-stationarity was not rejected.

${ }^{8}$ These results are available on request.
} 
Table 6: ADF tests for unit roots in price series of sea bream

\begin{tabular}{|l|l|l|l|l|l|}
\hline Prices in log & \multicolumn{1}{|c|}{$\begin{array}{c}\text { Test stat. } \\
\text { level }\end{array}$} & $\begin{array}{c}\text { Critical value } \\
\mathbf{( 5 \% )}\end{array}$ & Test stat. & Critical value & Critical \\
& & & $\mathbf{( 5 \% )}$ & value (10\%) \\
\hline Wild sea bream & $-3.649 * *$ & -3.000 & & & \\
\hline Farmed sea & $-2.993 *$ & -3.000 & $-2.750 *$ & -3.000 & -2.630 \\
\hline bream & & & & & \\
\hline
\end{tabular}

* Statistically significant at the $10 \%$ level; ** statistically significant at the 5\% level.

\section{Estimation Results for Sea Bass}

The estimates of the coefficients for the VAR model between wild and farmed sea bass are reported in table $7 .{ }^{9}$ Table 7 column 1 shows the results for the specification with just one lag (Model 1); column 2 includes the results for the specification with two lags (Model 2).

The empirical results for Model 2 show that only the fish price for the preceding year has a positive and significant effect on the current price regardless of whether it is the wild or the farmed product. This might indicate that producers take account of the one-year lagged fish price when making their production and catch decisions.

In both models, the price of farmed sea bass has a positive but not significant effect on the price of wild sea bass. This result holds also for the impact of the wild sea bass price on the price of its farmed counterpart.

\footnotetext{
${ }^{9}$ The models are estimated using the command varbasic in Stata.
} 
Table 7: VAR estimation of the log of the sea bass prices

\begin{tabular}{|c|c|c|}
\hline & $\begin{array}{c}(1) \\
\text { Model } 1\end{array}$ & $\begin{array}{c}(2) \\
\text { Model } 2\end{array}$ \\
\hline \multicolumn{3}{|l|}{ Wild sea bass } \\
\hline L.lp_wseabass & $\begin{array}{l}0.401 \\
(1.88)\end{array}$ & $\begin{array}{l}0.485^{*} \\
(2.39)\end{array}$ \\
\hline L2.lp_wseabass & & $\begin{array}{l}-0.269 \\
(-1.32)\end{array}$ \\
\hline L.lp_fseabass & $\begin{array}{l}0.192 \\
(1.31)\end{array}$ & $\begin{array}{l}0.704 \\
(1.81)\end{array}$ \\
\hline L2.lp_fseabass & & $\begin{array}{l}-0.439 \\
(-1.30)\end{array}$ \\
\hline _cons & $\begin{array}{c}1.017^{* * *} \\
(2.79)\end{array}$ & $\begin{array}{c}1.337^{* * *} \\
(3.54)\end{array}$ \\
\hline $\mathrm{R}^{2}$ & 0.47 & 0.48 \\
\hline $\begin{array}{l}\text { Farmed sea bass } \\
\text { L.lp_wseabass }\end{array}$ & $\begin{array}{l}0.026 \\
(0.22)\end{array}$ & $\begin{array}{l}0.057 \\
(0.56)\end{array}$ \\
\hline L2.lp_wseabass & & $\begin{array}{l}-0.119 \\
(-1.16)\end{array}$ \\
\hline L.lp_fseabass & $\begin{array}{c}0.808^{* * *} \\
(10.05)\end{array}$ & $\begin{array}{c}0.897^{* * *} \\
(4.57)\end{array}$ \\
\hline L2.lp_fseabass & & $\begin{array}{l}-0.111 \\
(-0.65)\end{array}$ \\
\hline _cons & $\begin{array}{l}0.253 \\
(1.26)\end{array}$ & $\begin{array}{c}0.497^{* *} \\
(2.62)\end{array}$ \\
\hline $\mathrm{R}^{2}$ & 0.91 & 0.91 \\
\hline$N$ & 20 & 19 \\
\hline$A I C$ & -32.12 & -34.10 \\
\hline
\end{tabular}


These results are confirmed when we test for Granger causality between the price series of sea bass. ${ }^{10}$ The results of Models 1 and 2 are reported in tables 8 and 9.

Table 8: Granger causality test for sea bass prices: Model 1 (with one lag)

\begin{tabular}{|l|l|l|l|}
\hline Equation & Test & Chi2 & Prob>Chi2 \\
\hline Wild sea bass price & Farmed sea bass price & 1.73 & 0.19 \\
\hline Farmed sea bass price & Wild sea bass price & 0.05 & 0.83 \\
\hline
\end{tabular}

Table 9: Granger causality for sea bass prices: Model 2 (with two lags)

\begin{tabular}{|l|l|l|l|}
\hline Equation & Test & Chi2 & Prob>Chi2 \\
\hline Wild sea bass price & Farmed sea bass price & 4.10 & 0.13 \\
\hline Farmed sea bass price & Wild sea bass price & 1.36 & 0.51 \\
\hline
\end{tabular}

The results in tables 8 and 9 show that the estimated coefficients of the lagged values of the explanatory variables are jointly zero. This means that the price of farmed sea bass has no causal impact on the price of wild sea bass. Similarly, we observe no price leadership from the price of wild sea bass to the price of farmed sea bass.

\section{Estimation Results for Sea Bream}

The estimates of the coefficients for the VAR model between wild and farmed sea bream are reported in table 10 . Table 10 column 1 presents the results for the specification with just one lag (Model 1), while column 2 includes the results for the specification with two lags (Model 2). Since we cannot reject the non-stationarity of the price series of farmed sea bream, we take their first-differences.

${ }^{10}$ This test is undertaken after VAR estimation using the command vargranger in Stata. 
Table 10: VAR estimation of the log of the sea bream prices

\begin{tabular}{|c|c|c|}
\hline & $\begin{array}{c}(1) \\
\text { Model } 1\end{array}$ & $\begin{array}{c}(2) \\
\text { Model } 2\end{array}$ \\
\hline $\begin{array}{l}\text { Wild sea bream } \\
\text { L.lp_wseabream }\end{array}$ & $\begin{array}{c}0.765^{* * *} \\
(7.46)\end{array}$ & $\begin{array}{c}0.646^{* *} \\
(2.68)\end{array}$ \\
\hline L2.1p_wseabream & & $\begin{array}{l}0.0635 \\
(0.26)\end{array}$ \\
\hline LD.lp_fseabream & $\begin{array}{c}0.749^{* * *} \\
(4.61)\end{array}$ & $\begin{array}{c}0.712^{* *} \\
(3.10)\end{array}$ \\
\hline L2D.lp_fseabream & & $\begin{array}{l}0.120 \\
(0.48)\end{array}$ \\
\hline _cons & $\begin{array}{l}0.515^{*} \\
(2.32)\end{array}$ & $\begin{array}{l}0.635 \\
(1.88)\end{array}$ \\
\hline $\mathrm{R}^{2}$ & 0.76 & 0.65 \\
\hline $\begin{array}{l}\text { First-diff. Farmed } \\
\text { sea bream } \\
\text { L.lp_wseabream }\end{array}$ & $\begin{array}{c}-0.461^{* * *} \\
(-4.42)\end{array}$ & $\begin{array}{c}-0.768^{* * *} \\
(-4.04)\end{array}$ \\
\hline L2.lp_wseabream & & $\begin{array}{l}0.014 \\
(0.07)\end{array}$ \\
\hline LD.lp_fseabream & $\begin{array}{l}0.032 \\
(0.19)\end{array}$ & $\begin{array}{l}-0.236 \\
(-1.31)\end{array}$ \\
\hline L2D.lp_fseabream & & $\begin{array}{l}0.277 \\
(1.41)\end{array}$ \\
\hline _cons & $\begin{array}{c}0.953^{* * *} \\
(4.21)\end{array}$ & $\begin{array}{c}1.576^{* * *} \\
(5.91)\end{array}$ \\
\hline $\mathrm{R}^{2}$ & 0.55 & 0.73 \\
\hline$N$ & 19 & 18 \\
\hline$A I C$ & -50.64 & -47.43 \\
\hline
\end{tabular}


To ease the reading of the results, we present the estimated equation for farmed sea bream price (recall that all prices are in log) for the specification with one lag (Model 1) ${ }^{11}$ :

$$
\begin{aligned}
& \left(x_{t}-x_{t-1}\right)=0.953^{* * * *}-0.461^{* * * *} y_{t-1}+0.032\left(x_{t-1}-x_{t-2}\right)+v_{x t} \\
& \Leftrightarrow x_{t}=0.953^{* * * *}-0.461^{* * * *} y_{t-1}+1.032 x_{t-1}-0.032 x_{t-2}+v_{x t}
\end{aligned}
$$

The empirical results indicate that the preceding yearôs wild sea bream price $\left(\mathrm{y}_{t-1}\right)$ has a negative and significant effect on the current price of farmed sea bream $\left(x_{t}\right)$. This result also holds for Model 2.

The estimated equation for wild sea bream price for Model 1 is:

$$
y_{t}=0.515^{*}+0.765^{* * * *} y_{t-1}+0.749^{* * * *} x_{t-1}-0.749^{* * * *} x_{t-2}+v_{y t}
$$

The empirical results indicate that the preceding yearôs wild sea bream price $\left(\mathrm{y}_{t-1}\right)$ has a positive and significant effect on the current price of wild sea bream $\left(\mathrm{y}_{t}\right)$. This result also holds for Model 2. As in the case of sea bass, this might indicate that producers take account of the one-year lagged fish price when making their catch decisions.

The empirical results also indicate that the price of farmed sea bream in the preceding year $\left(x_{t-1}\right)$ has a positive and significant effect on the current price of wild sea bream $\left(y_{t}\right)$. This result also holds for Model 2. Despite seasonal and random variations in the supply of wild sea bream, its price is determined partly by the price of farmed sea bream. This finding indicates the existence of potential demand effects in the sea bream market. To investigate this, we conduct an additional test for Granger causality between the price series of sea bream. The results from Models 1 and 2 are reported in tables 11 and 12.

\footnotetext{
${ }^{11}$ To save space, we do not present the estimated equation for Model 2 (with two lags).
} 
Table 11: Granger causality test for sea bream prices: Model 1 (with one lag)

\begin{tabular}{|l|l|l|l|}
\hline Equation & Test & Chi2 & Prob>Chi2 \\
\hline Wild sea bream price & $\begin{array}{l}\text { First-diff. farmed sea } \\
\text { bream price }\end{array}$ & 21.24 & 0.000 \\
\hline $\begin{array}{l}\text { First-diff. farmed sea } \\
\text { bream price }\end{array}$ & Wild sea bream price & 19.51 & 0.000 \\
\hline
\end{tabular}

Table 12: Granger causality for sea bream prices: Model 2 (with two lags)

\begin{tabular}{|l|l|l|l|}
\hline Equation & Test & Chi2 & Prob>Chi2 \\
\hline Wild sea bream price & $\begin{array}{l}\text { First-diff. farmed sea } \\
\text { bream price }\end{array}$ & 9.77 & 0.008 \\
\hline $\begin{array}{l}\text { First-diff. farmed sea } \\
\text { bream price }\end{array}$ & Wild sea bream price & 41.48 & 0.000 \\
\hline
\end{tabular}

The results in tables 11 and 12 show that the estimated coefficients of the lagged values of the explanatory variables are not jointly zero. This means that the variation in the price of farmed sea bream has a causal impact on the price of wild sea bream. Similarly, we observe that the price of wild sea bream Granger-causes the price variation in farmed sea bream.

Robustness Checks for the Results for Sea Bream

In the preceding regression, we consider the farmed sea bream price to be non-stationary. However, the stationarity test is not completely conclusive. To further investigate the stationarity of the farmed sea bream price series, we apply the Johansen cointegration test 
(Johansen, 1995) to find the number of cointegrating equations in a vector autoregressive model in error correction form (VECM). The results of the trace statistics reported in Appendix table 17 are, however, ambiguous: at the 5\% critical value, the wild and farmed sea bream price series are stationary, while at the $1 \%$ critical value, they are non-stationary but not cointegrated. Because of the weak power of the different stationarity tests, we check the robustness of the estimation results for sea bream by estimating three alternative models: a VAR model with (stationary) variables in level as defined in equation (1), a VAR model with (non-stationary but not cointegrated) variables in first-difference (for both wild and farmed sea bream prices) with one lag, and a vector error correction (VEC) model (with nonstationary and cointegrated variables). Even if our original sea bream model is badly specified, nevertheless the conclusions of all four models converge: the markets for wild and farmed sea bream are integrated.

Estimates of the coefficients of the VAR model for the price series in levels are reported in Appendix table 14. Table 14 column 1 presents the results for the specification with just one lag; column 2 presents the results for the specification with two lags. The empirical results show that the preceding yearôs price of farmed sea bream has a positive and significant effect $\left(0.473^{* * *}\right.$ for one-lag specification and $0.752^{* *}$ for two-lags $)$ on the wild sea breamôs current price. The t-statistics of these estimates have reasonable values; they are not extremely high as would be in the case of non-stationarity. The positive coefficients indicate a substitutional relationship between the price series in the short-term which is compensated partly by a complementary relationship at the next date $(-0.457 *)$.

The estimates of the coefficients for the VAR model between the price series in firstdifference are reported in Appendix table 15. The empirical results show that the variation in the price of farmed sea bream in the preceding year $\left(x_{t-1}-x_{t-2}\right)$ has a positive and significant 
effect $\left(0.987^{* * *}\right)$ on the current variation in the price of wild sea bream. This result is in line with the results of the VAR model in levels in terms of the substitution relationship between the price series of wild and farmed sea bream.

The estimates of the coefficients for the VEC model are reported in Appendix table 16. The empirical results show that the variation in the price of farmed sea bream in the preceding year $\left(x_{t-1}-x_{t-2}\right)$ has a positive and significant effect $\left(0.557^{* * *}\right)$ on the current variation in the price of wild sea bream. This means that wild and farmed sea bream are substitutes in the short-run, following the interpretation in Toda and Philipps (1993). The estimated cointegration equation (lp_wseabream-0.24lp_fseabream -1.7) also indicates the existence of a long-term substitutability between the two goods, following Toda and Philipps (1993).

\section{CONCLUDING REMARKS}

Turkey is one the main producers and exporters of farmed sea bass and sea bream in Europe. Turkey is the largest producer of sea bass in Europe, followed by Greece. This ranking is reversed for sea bream (FEAP, 2014). Turkey also catches wild sea bass and sea bream making the Turkish market an interesting case to investigate market interactions in the wild and farmed sea bass and sea bream markets. The market conditions for sea bass and sea bream have direct impacts on the European fish market, and vice versa.

We set out to investigate the interactions in the Turkish wild and farmed sea bass and sea bream markets. We provided descriptive statistics for the price dynamics in these markets, 
and conducted a Granger causality test on the prices of the wild and farmed products for both species, based on the estimation of a VAR model. The Granger causality tests take account of dynamic interactions between markets. Our data base includes annual domestic price series for wild and farmed fish from 1996 to 2016.

Our empirical results show that the price of farmed sea bass has no causal impact on the price of wild sea bass, and we observe no price leadership from the price of wild sea bass to the price of farmed sea bass indicating that they are neither substitutes nor complements. The markets for the two products are segmented. These results are in line with the findings in the literature. There is evidence of the absence of integration of the wild and farmed sea bass markets for Italy (Brigante and Lem, 2001), France (Régnier and Bayramoglu, 2016) and Spain (Bjorndal and Guillen, 2017). These results indicate that wild and farmed sea bass are neither substitutes nor complements : the markets for each product are independent.

In the case of sea bream, our empirical results show that the variation in the price of farmed sea bream has a causal impact on the price of wild sea bream, and similarly, the price of wild sea bream Granger-causes the price variation in farmed sea bream. These results indicate that the wild and farmed sea bream markets in Turkey are integrated. They have been confirmed by estimating three other alternative models for sea bream. Thus, marine catches of sea bream have clearly an endogenous economic part despite exogeneous determinants such as the instrinsic growth rate of fish, the carrying capacity of fish populations, fish migration patterns, etc.

Our results differ from those of Brigante and Lem (2001) for Italy, and Rodriguez et al. (2013) and Bjorndal and Guillen (2017) for Spain. In Italy and Spain, the price series of 
farmed and wild sea bream are not cointegrated which means that the farmed and wild sea bream markets are not integrated. Our results are closer to the findings in Régnier and Bayramoglu (2016) for France which show that the the French wild and farmed sea bream markets are partly integrated (namely, the two products are imperfect substitutes). We conducted a Granger causality test to take account of the dynamic interactions between markets. It turns out that those dynamics are needed to account for some delays in fish price formation. We chose not to implement only a cointegration approach because the three price series being considered are stationary, the price series are annual, and the sample is short, making cointegration inappropriate for our purposes.

These overall findings on sea bass and sea bream show that demand for fish is speciesspecific, and we cannot generalize from a study of a particular fish species.

Our study has some limitations. First, we mainly investigate the domestic prices of fish produced and caught in Turkey. Since we lack data on the export prices of Turkish wild and farmed sea bass and sea bream, we cannot investigate the effect of foreign demand on the formation of fish prices. Second, we use TurkStat data based on annual price statistics. However, these data are informative since they provide price data disaggregated between farmed and wild origin, data which are rarely available (Bjorndal and Guillen, 2017). We hope that a more complete data set that includes monthly statistics will become available in the near future to allow further research. 


\section{REFERENCES}

Akova, S. B. (2015). Aquaculture and Its Distribution in Turkey, Journal of Aquaculture Engineering and Fisheries, 1(4), 160-190.

Asche, F., Bjorndal, T. and Young, J., (2001): Market interactions for aquaculture products, Aquaculture Economics \& Management, Vol. 5(5-6), 303--318.

Asche, F., Gordon, D. V. and Hannesson, R., (2002): Searching for price parity in the European whitefish market, Applied Economics, Vol. 34(8), 1017-1024(8).

Asche, F., Guttormsen, A. G., Sebulonsen, T. and Sissener, E. H., (2005). Competition between farmed and wild salmon: the Japanese salmon market, Agricultural Economics, Vol. $33,333-340$.

Aydin, B., Yilmaz, S., and Gumus, E., (2014). Comparison of aquaculture production of Turkey and European Union, World Aquaculture Meeting 2014 conference paper.

Bjorndal, T. and Guillen, J. (2017): Market integration between wild and farmed seabream and seabass in Spain, Applied Economics, Vol. 49(45), 4567ï 4578.

Bourbonnais, R. (2000). Econométrie, Dunod 3ème edition, 314 p.

Bozoglu, M., and Ceyhan, V. (2009). Cost and profitability analysis for trout and sea bass production in the Black Sea, Turkey. Journal of Animal and Veterinary Advances, 8(2), 217222.

Brigante, R. and Lem, A., (2001). Price interaction between aquaculture and fishery, Working paper, XIII EAFE Conference, Salerno, April 2001.

Elliott, G., T. J. Rothenberg, and J. H. Stock. 1996. Efficient tests for an autoregressive unit root. Econometrica 64: 813 ï 836.

Enders, W. (2004). Applied Econometric Time Series. John Wiley \& Sons. 
Ergun, H. (2009), ñSu urunleri tuketimi ve dagitimiò, Yunus Arastirma Bulteni, No.2 (in Turkish).

European Market Observatory for Fisheries and Aquaculture Products (EUFOMA), (2016). The EU Fish Market, 2016 Edition, European Market Observatory for Fisheries and Aquaculture Products.

European Market Observatory for Fisheries and Aquaculture Products (EUFOMA), (2017). The EU Fish Market, 2017 Edition, European Market Observatory for Fisheries and Aquaculture Products.

European Networking Group for Integrated Marine Policy (EUNETMAR), (2014). Country fiche Turkey. Available at URL: https://webgate.ec.europa.eu/maritimeforum/sites/maritimeforum/files/Turkey_cf.pdf [Accessed 3 January 2018].

Federation of European Aquaculture Producers (FEAP), (2014). European Aquaculture Production Report 2004-2013, Federation of European Aquaculture Producers.

Granger, C. W. (1969). Investigating causal relations by econometric models and crossspectral methods. Econometrica: Journal of the Econometric Society, 424-438.

Granger, C. W., Newbold, P., (1974). Spurious regressions in econometrics. Journal of Econometrics, 2(2), 111-120.

Hamilton, J. D. (1994). Time Series Analysis (Vol. 2). Princeton: Princeton university press. Harlioglu, A.G. (2011), Present status of fisheries in Turkey, Rewiews in Fish Biology and Fisheries, vol. 21(4), 667-680.

International Monetary Fund (IMF), World Economic Outlook Database, April 2017 (www.imf.org).

Johansen, S. (1995). Likelihood-based Inference in Cointegrated Vector Autoregressive Models. Oxford University Press. 
Knapp, G., Roheim, C. A., and Anderson, J. L., (2007). The great salmon run: competition between wild and farmed salmon, TRAFFIC North America, Washington D.C.: World Wildlife Fund.

Koçak, Ö., and Tatlēilil, F.F., (2004). Cost analysis in gilthead sea bream (Sparus aurata Linnaeus, 1758) and sea bass (Dicentrarchus labrax Linnaeus, 1758) production in Milas District-Muj la Province, Turkey. Turkish Journal of Fisheries and Aquatic Sciences 4.1.

Kurtoglu, I.Z., Kucuk, H., Alkan, A., Özdemir, A., (2010). Economic analysis and sustainability of Turkish marine hatcheries. Turkish Journal of Fisheries and Aquatic Sciences 10.4 (2010).

Nielsen, M., (2005). Price formation and market integration on the European first-hand market for whitefish, Marine Resource Economics, Vol. 20, 185-202.

OkumuK K, and Deniz, H. (2007). Past, present and future of the marine aquaculture. Marine Aquaculture in Turkey. Candan A., Karatas S., Kucuktas H., Okumus K̦(eds.) (2007): 71-77.

Ozguler, H. (2007). Marketing and economic perspective. Marine Aquaculture in Turkey. Candan A., Karatas S., Kucuktas H., Okumus K̦(eds.) (2007): 117-125.

Phillips, P. C. B., and P. Perron. 1988. Testing for a unit root in time series regression. Biometrika 75: 335 ï 346.

Rad F., (2002). Country report: Turkey. In: Paquotte P. (ed.), Mariojouls C. (ed.), Young J. (ed.). Seafood market studies for the introduction of new aquaculture products. Zaragoza: CIHEAM, 2002. p. 341 -372 (Cahiers Options Méditerranéennes; n. 59)

Rad, F., and Köksal, G., (2000). An overview of aquaculture in Turkey: with emphasis on sea bass and sea bream. Aquaculture Economics \& Management 4.3-4 (2000): 227-239.

Rad, F., and Rad, S. (2012). A Comparative Assessment of Turkish Inland Fisheries and Aquaculture Using Economic Sustainability Indicators. Turkish Journal of Fisheries and Aquatic Sciences, 12(2), Ferit-Rad.

Regnier, E., and Bayramoglu, B. (2016). Competition between farmed and wild fish: the French sea bass and sea bream markets. Aquaculture Economics \& Management: 1-21. 
Rodriguez, R.G., Bande, R., Villasante, S. (2013). Origins matter: (no) market integration between cultured and wild gilthead sea bream in the Spanish seafood market, Aquaculture Economics \& Management, Vol. 17(4), 380-397.

State Planning Organization (SPO) (2014), The Tenth Development Plan (2014-2018), Fishery Products, Report of the Private Expert Commission, The Ministry of Development of the Republic of Turkey, Ankara (in Turkish).

Ulman, A., Bekisoglu, S., Zengin, M. A., Knudsen, S., Unal, V., Mathews, C., ... \& Pauly, D. (2013). From bonito to anchovy: a reconstruction of Turkeyô marine fisheries catches (19502010). Mediterranean Marine Science, 14(2), 309-342.

Toda, H. Y., \& Phillips, P. C. (1993). Vector autoregressions and causality. Econometrica: Journal of the Econometric Society, 1367-1393.

Turkish Statistics Institute (TurkStat) (2017), Fishery Products 2016, Press Release No: 24657, 23 June 2017. 


\section{APPENDIX}

Table 13: Consumption (kg) of fresh fish (including farmed/wild and sea/inland) by species

\begin{tabular}{|c|c|c|c|}
\hline ranking fresh fish & Turkish name & English name & quantity (kg) \\
\hline 1 & Hamsi & anchovy & 8994538 \\
\hline 2 & Kstavrit & horse mackerel & 1682424 \\
\hline 3 & Sardalya & european pilchard & 901914 \\
\hline 4 & Sazan & carp & 749928 \\
\hline 5 & Mezgit & whiting & 657532 \\
\hline 6 & Kefal & goldon grey mullet & 399769 \\
\hline 7 & Palamut & atlantic bonito & 382541 \\
\hline 8 & Çinekop & small bluefish & 314789 \\
\hline 9 & Alabalđ̄ & trout & 314751 \\
\hline 10 & Çupra & sea bass & 304218 \\
\hline 11 & Taze BalǢ Dijer & other fresh fish & 206818 \\
\hline 12 & Van Gölü Balệ̄ & fish of Lake Van & 183939 \\
\hline 13 & Uskumru & atlantic mackerel & 147438 \\
\hline 14 & Levrek & sea bass & 137321 \\
\hline 15 & Barbunya & red mullet & 123883 \\
\hline 16 & GümüK & silverside & 98585 \\
\hline 17 & Lüfer & bluefish & 86324 \\
\hline 18 & Karabalæ̋ (Yöresel) & North African catfish & 70936 \\
\hline 19 & Mercan & striped bream & 61174 \\
\hline 20 & Somon & atlantic salmon & 46165 \\
\hline 21 & Kadife & tench & 37976 \\
\hline 22 & Turna & pickerel & 35690 \\
\hline 23 & Sarø̄alథ (Yöresel) & a large carp & 31476 \\
\hline 24 & Zargana & garfish & 19691 \\
\hline 25 & Tirsi & twaite shad & 18982 \\
\hline 26 & Tekir & striped red mullet & 18096 \\
\hline 27 & Karagöz & two-baded sea bream & 17443 \\
\hline 28 & Kब̄ę & swordfish & 16704 \\
\hline 29 & K女marit & picarel & 15569 \\
\hline
\end{tabular}




\begin{tabular}{|l|l|l|c|}
\hline 30 & Kolyoz & chup mackerel & 14872 \\
\hline 31 & Dil & common sole & 12781 \\
\hline 32 & $\begin{array}{l}\text { Sazan Bulgar Sazanēē } \\
\text { (Yöresel) }\end{array}$ & bulgarian carp & 10134 \\
\hline 33 & Torik & a large bonito & 7519 \\
\hline 34 & Yayē̄ & catfish & 7398 \\
\hline 35 & Lagos (lahoz) & white grouper & 3493 \\
\hline 36 & Feki & not available & 2630 \\
\hline 37 & Kēlangē̄e & east atlantic red gurnard & 1835 \\
\hline 38 & Kalkan & turbot & 1751 \\
\hline 39 & Pavurya & green crab & 332 \\
\hline
\end{tabular}

Source: Own calculations based on Househould Budget Survey 2003 micro data (TurkStat). 
Table 14: VAR estimation of the log of the sea bream prices in level

\begin{tabular}{|c|c|c|}
\hline & $\begin{array}{c}(1) \\
\text { One lag }\end{array}$ & $\begin{array}{c}\text { (2) } \\
\text { Two lags }\end{array}$ \\
\hline $\begin{array}{l}\text { Wild sea bream } \\
\text { L.lp_wseabream }\end{array}$ & $\begin{array}{l}0.102 \\
(0.52)\end{array}$ & $\begin{array}{l}0.506^{* *} \\
(3.26)\end{array}$ \\
\hline L2.lp_wseabream & & $\begin{array}{l}-0.197 \\
(-1.18)\end{array}$ \\
\hline L.lp_fseabream & $\begin{array}{c}0.473^{* * *} \\
(3.80)\end{array}$ & $\begin{array}{c}0.752^{* * *} \\
(4.04)\end{array}$ \\
\hline L2.lp_fseabream & & $\begin{array}{l}-0.457^{*} \\
(-2.13)\end{array}$ \\
\hline _cons & $\begin{array}{c}1.083^{* * *} \\
(3.80)\end{array}$ & $\begin{array}{c}0.973^{* * *} \\
(3.30)\end{array}$ \\
\hline $\mathrm{R}^{2}$ & 0.71 & 0.82 \\
\hline $\begin{array}{l}\text { Farmed sea bream } \\
\text { L.lp_wseabream }\end{array}$ & $\begin{array}{c}-0.513^{* *} \\
(-3.16)\end{array}$ & $\begin{array}{l}-0.401^{*} \\
(-2.21)\end{array}$ \\
\hline L2.lp_wseabream & & $\begin{array}{l}-0.167 \\
(-0.86)\end{array}$ \\
\hline L.lp_fseabream & $\begin{array}{l}1.069^{* * * *} \\
(10.37)\end{array}$ & $\begin{array}{c}0.908^{* * *} \\
(4.17)\end{array}$ \\
\hline L2.lp_fseabream & & $\begin{array}{l}0.115 \\
(0.46)\end{array}$ \\
\hline _cons & $\begin{array}{c}0.947^{* * *} \\
(4.01)\end{array}$ & $\begin{array}{c}1.142^{* * *} \\
(3.30)\end{array}$ \\
\hline $\mathrm{R}^{2}$ & 0.82 & 0.87 \\
\hline$N$ & 20 & 19 \\
\hline$A I C$ & -44.01 & -49.43 \\
\hline
\end{tabular}


Table 15: VAR estimation of the log of the sea bream prices in first-difference

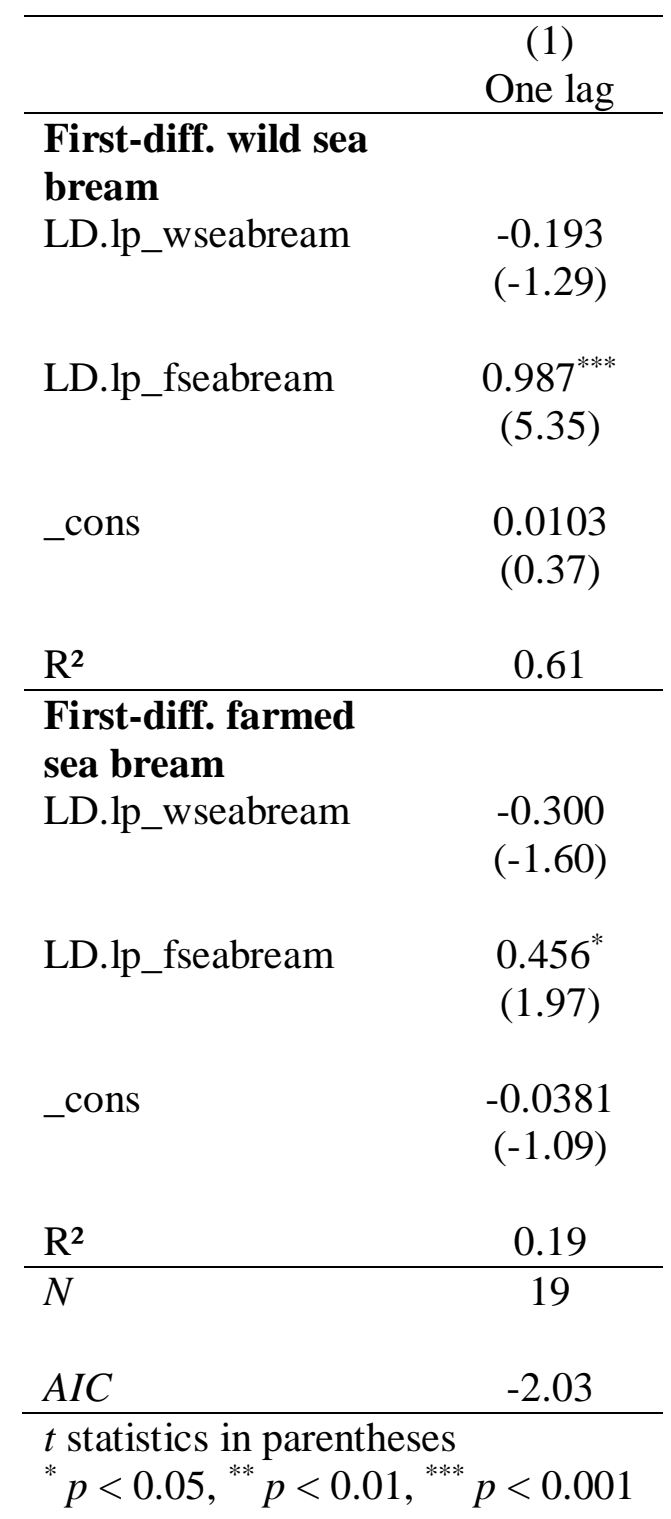


Table 16: VECM estimation of the log of the sea bream prices

(1)

\begin{tabular}{|c|c|}
\hline $\begin{array}{l}\text { First-diff. wild sea } \\
\text { bream } \\
\text { L._ce1 }\end{array}$ & $\begin{array}{c}-0.487^{*} \\
(-2.43)\end{array}$ \\
\hline LD.lp_wseabream & $\begin{array}{l}0.144 \\
(0.72)\end{array}$ \\
\hline LD.lp_fseabream & $\begin{array}{l}0.557^{*} \\
(2.23)\end{array}$ \\
\hline _cons & $\begin{array}{c}0.0247 \\
(0.91)\end{array}$ \\
\hline $\mathrm{R}^{2}$ & 0.74 \\
\hline $\begin{array}{l}\text { First-diff. farmed } \\
\text { sea bream } \\
\text { L._ce1 }\end{array}$ & $\begin{array}{c}-0.743^{* *} \\
(-3.27)\end{array}$ \\
\hline LD.lp_wseabream & $\begin{array}{l}0.213 \\
(0.94)\end{array}$ \\
\hline LD.lp_fseabream & $\begin{array}{l}-0.200 \\
(-0.71)\end{array}$ \\
\hline _cons & $\begin{array}{c}-0.0162 \\
(-0.52)\end{array}$ \\
\hline $\mathrm{R}^{2}$ & 0.58 \\
\hline$N$ & 19 \\
\hline$A I C$ & -2.47 \\
\hline
\end{tabular}


Table 17: Bivariate Johansen test between wild and farmed sea bream prices

\begin{tabular}{|l|l|l|l|}
\hline $\begin{array}{l}\text { Maximum } \\
\text { rank }\end{array}$ & $\begin{array}{l}\text { Trace } \\
\text { statistic }\end{array}$ & $\begin{array}{l}5 \% \text { critical } \\
\text { value }\end{array}$ & $\begin{array}{l}1 \% \text { critical } \\
\text { value }\end{array}$ \\
\hline 0 & $18.9019^{*}$ & 15.41 & 20.04 \\
\hline 1 & 4.4726 & 3.76 & 6.65 \\
\hline 2 & & & \\
\hline
\end{tabular}

